\title{
Pengembangan Media Pembelajaran Matematika Interaktif Berbasis Android Pada Materi Bentuk Aljabar
}

\author{
Dinda Qori Wahyuni ${ }^{1}$, Rusydi Ananda ${ }^{2}$ \\ ${ }^{1,2}$ Program Studi Pendidikan Matematika, FITK, Universitas Islam Negeri Sumatera Utara, \\ J1. William Iskandar Ps. V, Medan Estate, Indonesia \\ dindaqori5@gmail.com
}

\begin{abstract}
The rapid technological development certainly assists the education world requiring it to be more modern. One of the ways can be done is by developing Android-based instructional media. The study aimed to develop interactive Android-based instructional media on algebraic form material. It was development research using ADDIE research model. The result of the study indicated that the developed instructional media met the validity index $\geq 61 \%$. The average validation result of media experts was $95.8 \%$ and material expert is $95.2 \%$ which are categorized as very valid. The results of the practicality test of the media obtained an average value percentage of $93.05 \%$ with a very practical category so that this media was practical. The result of small-scale testing of the developed instructional media can improve the student learning outcomes on algebra basics. This was proved by the increase in the average pre-test result from 43.33 to 79.13 in the post-test value and strengthened by the $\mathrm{N}$ Gain average value of 0.5 in the moderate category and $63.67 \%$ in the moderately effective category. Thus, it can be concluded that this learning media met the criteria of validity, practicality, and effectiveness.
\end{abstract}

Keywords: Interactive Instructional Media, Android, Algebra

\begin{abstract}
Abstrak
Adanya perkembangan teknologi yang sangat pesat berpengaruh dengan dunia pendidikan yang mengharuskan untuk lebih modern. Salah satunya yaitu dengan mengembangkan media pembelajaran yang berbasis android. Adapun tujuan dari penelitian ini ialah untuk mengembangkan media pembelajaran interaktif yang berbasis android pada materi bentuk aljabar. Penelitian ini merupakan penelitian pengembangan dengan menggunakan model penelitian ADDIE. Hasil dari penelitian ini menyatakan bahwa media pembelajaran yang dikembangkan memenuhi indeks kevalidan $\geq 61 \%$. Dengan rata-rata hasil validasi ahli media sebesar 95,8\% dan 95,2\% dari ahli materi dengan kategori sangat valid. Adapun hasil uji kepraktisan media diperoleh persentase nilai ratarata sebesar 93,05\% dengan kategori sangat praktis sehingga media ini praktis untuk digunakan. Hasil uji coba skala kecil media pembelajaran yang dikembangkan mampu meningkatkan hasil belajar siswa pada materi bentuk aljabar, hal ini dibuktikan dengan meningkatnya rata-rata hasil pretest 43,33 menjadi 79,13 pada nilai posttest dan diperkuat dengan nilai rata-rata $\mathrm{N}$-Gain sebesar 0,5 dengan kategori sedang dan 63,67\% dengan kategori cukup efektif. Dapat disimpulkan bahwa media pembelajaran ini memenuhi kriteria kevalidan, kepraktisan dan keefektifan.
\end{abstract}

Kata kunci: Media Pembelajaran Interaktif, Android, Bentuk Aljabar

Copyright (c) 2022 Dinda Qori Wahyuni, Rusydi Ananda

$\triangle$ Corresponding author: Dinda Qori Wahyuni

Emaildindaqori5@gmail.com (Jl. William Iskandar Ps. V, Medan Estate, Indonesia)

Received 17 January 2022, Accepted 26 January 2022, Published 14 February 2022

\section{PENDAHULUAN}

Di era globalisasi sekarang ini dimana perkembangan teknologi sudah sangat pesat, terutama dibidang informasi dan komunikasi seperti smartphone. Smartphone merupakan alat komunikasi yang sering digunakan dalam kehidupan sehari-hari dan hampir setiap individu memilikinya (Khuzaini \& Sulistyo, 2020). Salah satu smartphone yang banyak digunakan saat ini ialah smartphone yang berbasis android. Android merupakan sebuah system operasi pada perangkat mobile yang berbasis Linux dan mencakup system operasi, middleware dan aplikasi (Dwinata et al., 2016). Android ini dirancang untuk perangkat seluler seperti smartphone dan komputer tablet. 
Seperti yang kita ketahui, di era globalisasi ini banyak kita temui proses pembelajaran yang sudah menggunakan aplikasi android. Menurut hasil penenelitian (Mulyani, 12018), Penggunaan aplikasi android pada peserta didik dapat mengubah pembelajaran menjadi lebih efektif dan dapat meningkatkan hasil belajar siswa. Adapun salah satu bentuk pemanfaatan aplikasi android ialah pada pembelajaran matematika. Matematika merupakan ilmu pokok yang berperan penting di kehidupan manusia serta dalam pengembangan ilmu pengetahuan dan teknologi (IPTEK). Matematika dipelajari dan dikembangkan untuk meningkatkan daya pikir siswa dalam menghadapi kemajuan IPTEK (Hudojo, 12005). Dengan berkembangnya Ilmu Pengetahuan dan Teknologi menuntut seseorang agar dapat menguasai informasi dan pengetahuan. Di era teknologi sekarang ini, perkembangan dari Ilmu Pengetahuan dan Teknologi terhadap proses pembelajaran semangkin meningkat. Bahkan kini tak dapat dipungkiri bahwa multimedia berkembang ke arah yang lebih dinamik terutama dalam proses belajar mengajar. (Budiman, 12016).

Multimedia interaktif ialah suatu tampilan multimedia yang dirancang untuk dapat menginformasikan pesan secara interaktif dengan pengguna (Munir, 12012). Hal ini sejalan dengan pendapat (Daryanto, 12010) yang menyatakan bahwa multimedia interaktif ialah multimedia yang menggunakan alat pengontrol yang dapat dioperasikan oleh pengguna. Berdasarkan pendapat tersebut, dapat kita ketahui bahwa ciri dari multimedia interaktif ialah memiliki alat pengontrol untuk dapat menjalankan multimedia sesuai yang diinginkan.

Adapun media yang digunakan dalam penelitian ini ialah multimedia interaktif yang berbentuk audio visual dan berbasis android. Audio visual merupakan serangkaian gambar bergerak yang dipadukan dengan suara (Ernanida, 2019) \& (Sulfemi dan Nurhasanah, 2018). (Yektyastuti \& Ikhsan, 2016) mengatakan bahwa penggunaan media pembelajaran berbasis android termasuk penerapan gaya belajar di abad ke 21. Selain itu, pemilihan media pembelajaran interaktif yang tepat juga dapat memberikan manfaat yang besar terhadap guru maupun siswa (Daryanto, 2010). Media pembelajaran merupakan alat bantu sebagai perantara komunikasi untuk menyampaikan informasi ke penerima informasi guna tercapainya tujuan pembelajaran (Ramli, 2015). Hal ini sejalan dengan penelitian (Lestari et al., 2019) serta (Lestari dan Istiqomah, 2017), yang menyatakan bahwa adanya pengembangan dalam media pembelajaran yang berbasis android akan meningkatkan minat belajar dan menjadikan pembelajaran dikelas menjadi lebih efektif.

Berdasarkan hasil observasi yang telah dilakukan di MTs Al-Washliyah Pematangsiantar, guru masih cenderung menggunakan metode ekspositori seperti ceramah dan bantuan buku ajar dengan media papan tulis. Hal ini sejalan dengan penelitian (Sattriawan et al., 2020) \& (Putri \& Sibuea, 2014) dimana guru masih menggunakan metode konvensional dan kurang memanfaatkan multimedia dalam proses pembelajaran yang mengakibatkan kurangnya minat belajar dan rendahnya hasil belajar siswa. Selain itu guru juga belum pernah menggunakan bantuan media pembelajaran berbasis komputer maupun android seperti powerpoint dan aplikasi pembelajaran lainnya dalam menyampaikan materi. Hal ini dikarenakan kurangnya pengetahuan guru dalam mengembangkan 
media pembelajaran yang berbasis teknologi dan proses persiapan pembelajaran menggunakan media interaktif memakan waktu yang lama. (Komariah et al., 2018) mengungkapkan bahwa siswa sangat tertarik dan antusias dalam belajar ketika guru menggunakan media interaktif dalam proses pembelajaran, hanya saya penggunaan media tersebut tidak diterapkan pada setiap materi, karena proses persiapannya yang terlampau lama.

Sementara hasil wawancara yang dilakukan dengan guru mata pelajaran di sekolah MTs AlWashliyah Pematangsiantar, diketahui bahwa hasil belajar matematika siswa tergolong rendah dan guru masih menggunakan metode konvensional dalam mengajarkan materinya kepada siswa. Berdasarkan hasil angket yang diisi oleh siswa, peneliti memperoleh bahwa siswa mudah merasa bosan ketika guru menjelaskan materi yang sulit untuk mereka pahami. (Komariah et al., 2018) \& (Halimah \& Andi Mattoliang, 2020) mengungkapkan bahwa siswa merasa bosan belajar dengan metode belajar yang digunakan oleh guru, seperti metode ceramah, diskusi dan latihan. Sehingga apa yang disampaikan oleh guru tidak dapat dimengerti oleh siswa. Hal ini mengakibatkan siswa menjadi malas membaca buku dan mengerjakan tugas yang diberikan oleh guru. Oleh sebab itu, perlu dikembangkannya media pembelajaran yang tidak membosankan sehingga menimbulkan niat belajar siswa.

Berdasarkan permasalahan tersebut, peneliti ingin mengembangkan suatu media pembelajaran interaktif yang berbasis android untuk membatu proses pemahaman matematika siswa pada materi bentuk aljabar. Adapun penelitian sebelumnya yang telah mengembangkan media interaktif berbasis android dalam pembelajaran, contohnya penelitian yang dilakukan (Dwiranata et al., 2019) yang mengembangkan media pembelajaran interaktif berbasis android pada materi dimensi tiga dan penelitian (Hapsari dan Fahmi, 2021) yang mengembangkan media pembelajaran interaktif berbasis android pada operasi pada matriks. Hanya saja belum terdapat penelitian pengembangan media pembelajaran matematika interaktif berbasis android pada materi bentuk aljabar. Selain itu, peneliti juga menambahkan pengayaan soal dan quiz aljabar untuk melatih pemahaman siswa pada materi yang disampaikan.

Adapun tujuan dari penelitian ini ialah menciptakan suatu media pembelajaran interaktif yang valid, praktis dan efektif dilengkapi dengan pengayaan soal dan quiz aljabar. Selain itu, pembuatan jurnal ini juga dikarenakan belum adanya penelitian yang membahas secara serentak mengenai media ini. Peneliti berharap media ini dapat merubah proses pembelajaran menjadi lebih efektif dan tidak membosankan serta dapat meningkatkan hasil belajar siswa.

\section{METODE}

Jenis penelitian yang digunakan ialah Research \& Development (R\&D) atau penelitian pengembangan. Penelitian pengembangan merupakan suatu proses untuk menghasilkan sebuah produk yang bertujuan untuk melihat kelayakan dan keefektifan dari produk tersebut (Arliza et al., 2019). Pada penelitian ini, peneliti ingin mengembangkan suatu media pembelajaran matematika 
interaktif berbasis android pada materi bentuk aljabar. Penelitian ini menggunakan model pengembangan ADDIE yang mengarah pada pendapat Steven J McGriff. Adapun model ini terdiri dari lima tahap yaitu :

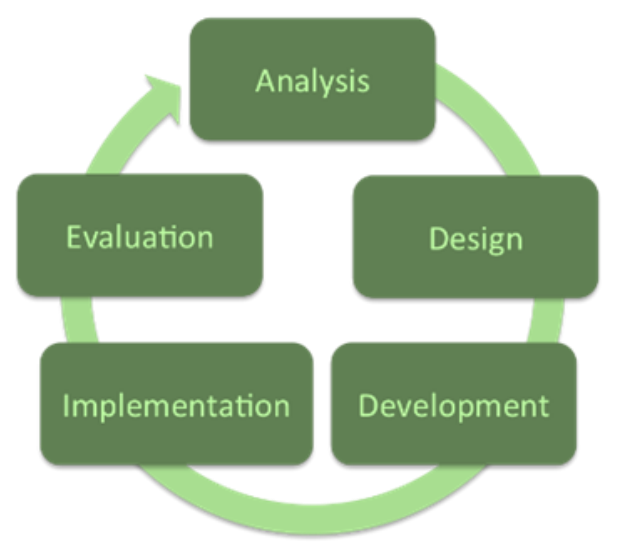

Gambar 1. Model Pengembangan ADDIE

Pada tahap analysis (analisis), peneliti menganalisis kebutuhan dengan melakukan wawancara terhadap guru dan memberikan angket kepada siswa kelas VII MTs Al-Washliyah Pematangsiantar. Hal ini dilakukan untuk mengetahui fakta dan masalah yang terjadi di lapangan.

Pada tahap design (perancangan), peneliti merancang media pembelajaran yang ingin dibuat. Tahap ini meliputi pembuatan desain media, penyusunan materi, soal dan jawaban serta pembuatan background, animasi dan tombol navigasi yang akan diberikan pada aplikasi tersebut.

Pada tahap development (pengembangan), peneliti membuat produk sesuai dengan desain yang telah dibuat. Media pembelajaran interaktif ini dikembangkan dengan aplikasi PPT, iSpring Suite 9 dan Website 2 APK. Setelah selesai dikembangkan kemudian media tersebut akan divalidasi oleh para ahli. Hasil dari penilaian para ahli inilah yang akan menentukan layak atau tidaknya media tersebut diuji cobakan kepada pengguna. Setelah divalidasi, langkah selanjutnya ialah merevisi media, jika media sudah memenuhi kriteria maka media siap untuk diuji cobakan kepada peserta didik.

Pada tahap implementation (implementasi), peneliti menguji validasi media dan validasi materi kepada para ahli. Kemudian dilakukan penilaian kepraktisan media oleh 12 orang siswa kelas VII dengan menmberikan kuesioner/angket untuk menilai kepraktisan media . Setelah melalui uji validitas dan kepraktisan, peneliti juga akan melakukan uji coba skala kecil terhadap 12 orang siswa kelas VII tersebut. Dengan langkah-langkah sebagai berikut:

1. Subjek melakukan pretest untuk mengetahui kemampuan kognitif mereka.

2. Subjek melakukan uji coba media pembelajaran interaktif. Pada tahap ini juga akan diperoleh saran dan responsden pengguna yang hasilnya akan menjadi bahan evaluasi media pembelajaran.

3. Dan terakhir kita akan melakukan posttest untuk mengetahui keefektifan media tersebut. 
Data hasil pretest dan postest siswa yang telah terkumpul diuji normalitas datanya kemudian dianalisis apakah ada perbedaan yang signifikan antara rata-rata nilai postest dengan pretest melalui Uji Paired Sample T-test. Setelah itu peneliti menggunakan Uji N-gain untuk mengetahui efektifitas penggunaan media pembelajaran tersebut.

Pada tahap evaluation (evaluasi), peneliti melakukan proses penilaian uji coba media untuk menilai kepraktisan, kevalidan dan keefektifan media. Keefektifan media tersebut akan dilihat berdasarkan peningkatan hasil pretest yang telah dilakukan. Teknik analisis validitas dan kepraktisan media yang digunakan dalam penelitian ini ialah dengan menyebarkan angket skala Likert dengan 5 opsi jawaban. Selanjutnya data kualitatif yang didapat diubah terlebih dahulu berdasarkan skor yang telah ditetapkan menjadi data kuantitatif. Besar persentasenya dihitung dengan rumus berikut:

$$
\text { Persentase }=\frac{\text { Jumlah skor yang didapat }}{\text { Jumlah skor maksimum }} \times 100 \%
$$

Kategori kelayakan dapat dilihat berdasarkan kriteria berikut:

Tabel 3. Kriteria Kelayakan Media

\begin{tabular}{|c|c|c|}
\hline No & Skor $(\%)$ & Kategori Kelayakan \\
\hline 1 & $<21 \%$ & Sangat Tidak Layak \\
\hline 2 & $21 \%-40 \%$ & Tidak Layak \\
\hline 3 & $41 \%-60 \%$ & Cukup Layak \\
\hline 4 & $61 \%-80 \%$ & Layak \\
\hline 5 & $81 \%-100 \%$ & Sangat Layak \\
\hline
\end{tabular}

(Arikunto \& Jabar, 2009)

\section{HASIL DAN DISKUSI}

Adapun hasil dari penelitian ini ialah berupa media pembelajaran interaktif berbasis android. Sehingga media pembelajaran ini dapat digunakan di smartphone yang menggunakan system operasi android sehingga dapat diakses oleh siswa dimanapun dan kapanpun. Media ini dikembangkan melalui tahapan-tahapan sebagai berikut:

\section{Tahap Analisi Kebutuhan}

Pada tahap ini, peneliti menemukan bahwa guru membutuhkan media pembelajaran yang berbasis android untuk membantu guru dalam menyampaikan materi kepada siswa. Hal ini sangat diperlukan, karena siswa akan mudah bosan jika guru hanya menggunakan metode ceramah saja dalam menyampaikan materinya. Menurut (Putra let lal., 12017), media pembelajaran interaktif berpotensi untuk meningkatkan respons positif siswa akan materi yang disampaikan dan media interaktif ini dapat meningkatkan hasil belajar siswa. Berdasarkan hal tersebut, peneliti tertarik untuk mengembangkan media pembelajaran berbasis android, yaitu berupa sebuah aplikasi pembelajaran. Adapun kebaruan dari media pembelajaran ini ialah berbentuk aplikasi yang dapat digunakan di android yang memuat materi dan penjelasannya, pengayaan soal dan evaluasi terkait materi dasar aljabar. 


\section{Tahap Desain dan Pengembangan}

Pada tahap desain, peneliti membuat rancangan materi seperti Kopetensi Dasar, Indikator Materi, Contoh Soal dan Jawaban, serta evaluasi materi Pembelajaran yang digunakan dalam media pembelajaran interaktif terkait materi dasar aljabar. Langkah berikutnya ialah peneliti menginstal aplikasi yang akan digunakan dalam membuat media pembelajaran tersebut, aplikasinya ialah Ispring Suit 9, Apk Builder dan Powerpoint. Setelah itu, peneliti membuat rancangan layout, menentukan background, gambar, animasi yang digunakan, bentuk font serta tombol navigasi yang akan digunakan didalam aplikasi tersebut. Pada tahap pengembangan dilakukan pembuatan media pembelajaran dengan aplikasi PPT dan iSpring Suit 9, dan hasilnya akan dijadikan aplikasi yang dapat diinstal pada android menggunakan Apk Builder. Selanjutnya pada tampilan menu utama terdapat menu fungsi tombol, kopetensi dasar, materi dan evaluasi.

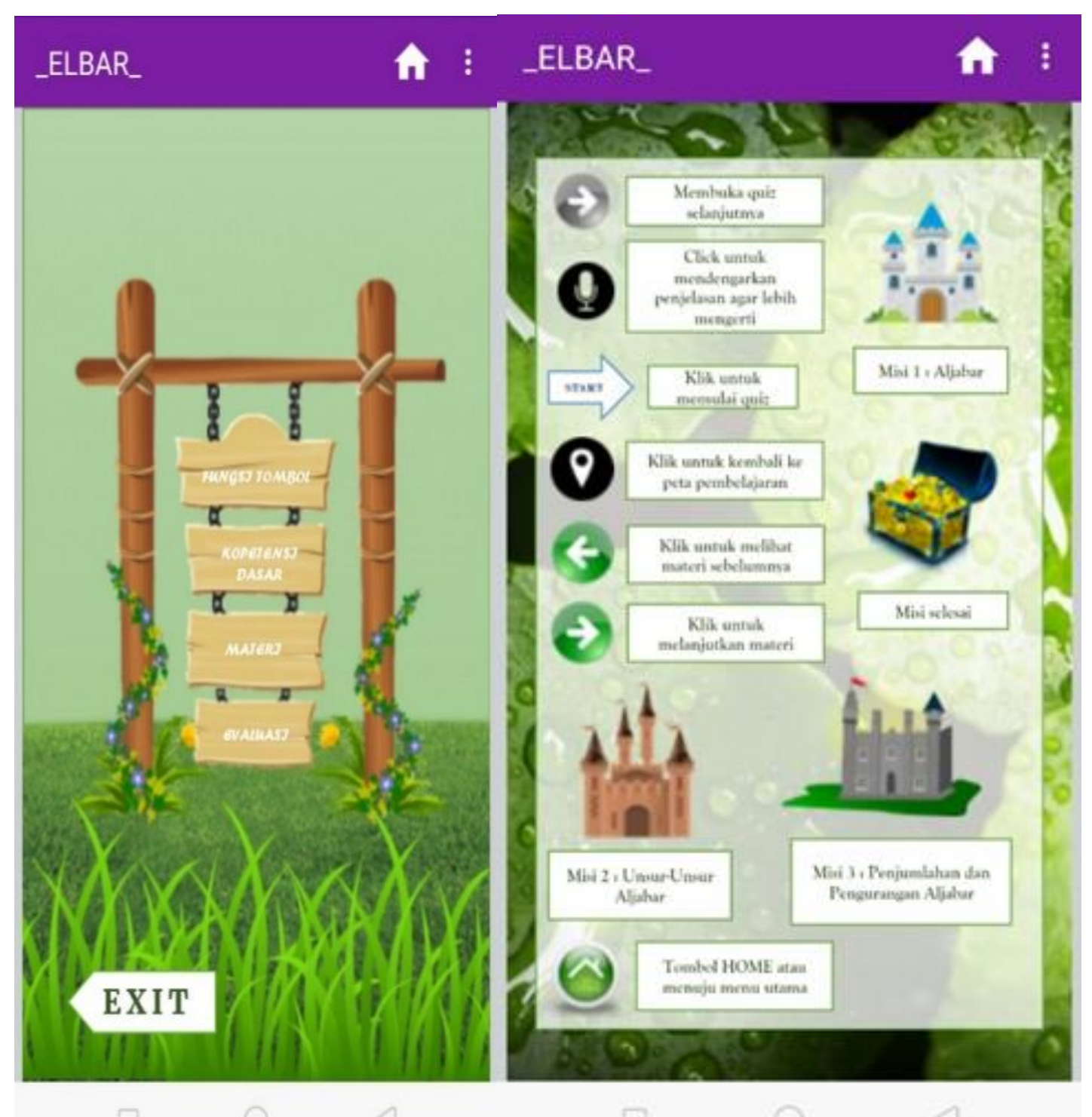

Gambar 3. Tampilan Menu Utama

Gambar 4. Tampilan Fungsi Tombol 
Pada menu materi terdapat peta pembelajaran yang mencakup materi pengenalan dasar aljabar, unsur-unsur aljabar serta operasi penjumlahan dan pengurangan aljabar.

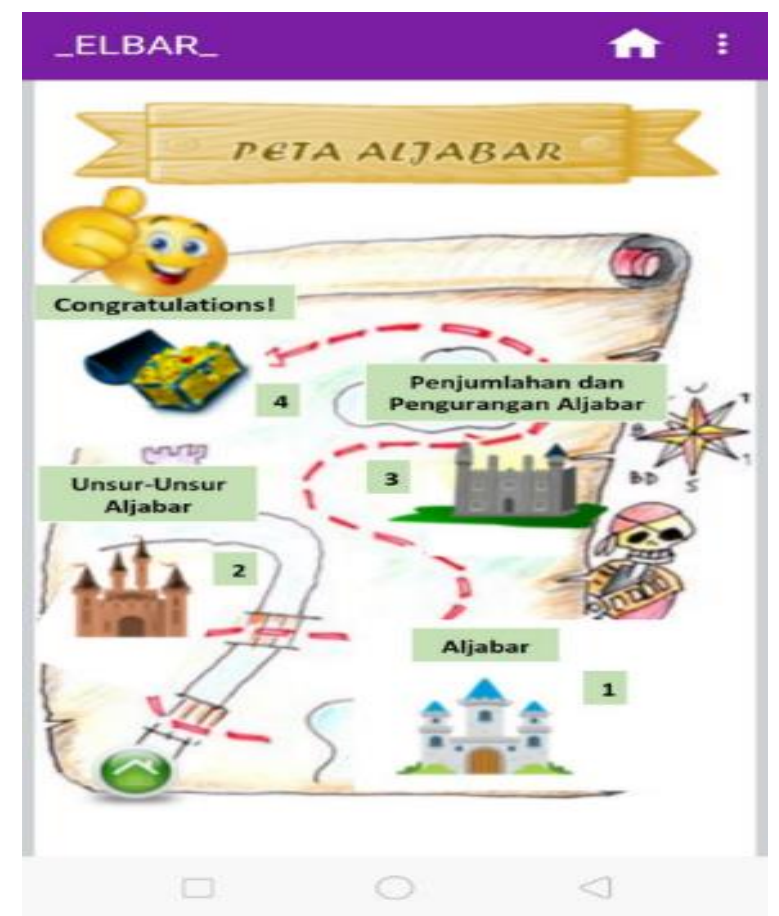

Gambar 6. Tampilan Menu Peta Materi

Setelah pengguna menekan gambar yang ada di peta maka akan ditampilkan isi materi. Tetapi pengguna hanya akan melanjut ke materi selanjutnya setelah menyelesaikan quiz yang ada pada setiap materinya. Apabila pengguna tidak bisa menyelesaikan soal yang diberikan maka pengguna dapat menekan tombol belajar kembali untuk mengulangi belajar materi tersebut. Dan jika jawaban pengguna salah maka akan muncul respons dari soal tersebut, begitupun sebalikanya. Begitulah hingga pengguna dapat menyelesaikan peta pembelajaran tersebut.

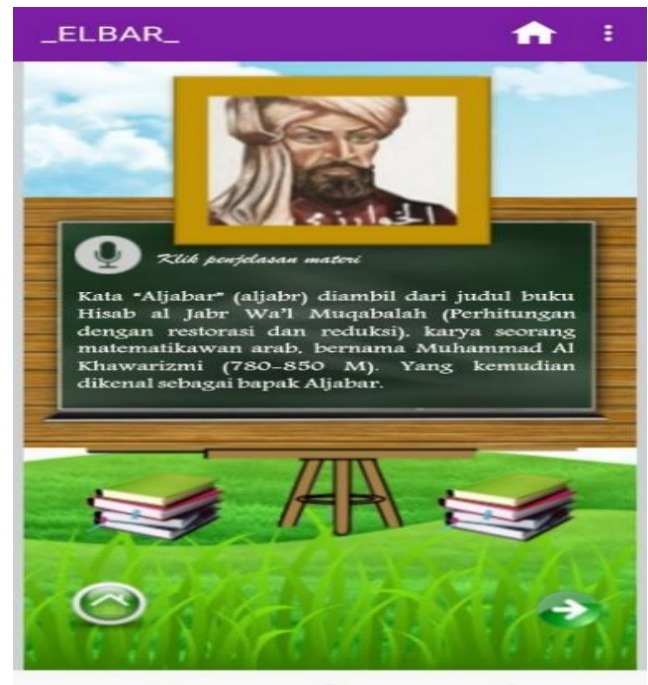

Gambar 7. Tampilan Isi Materi

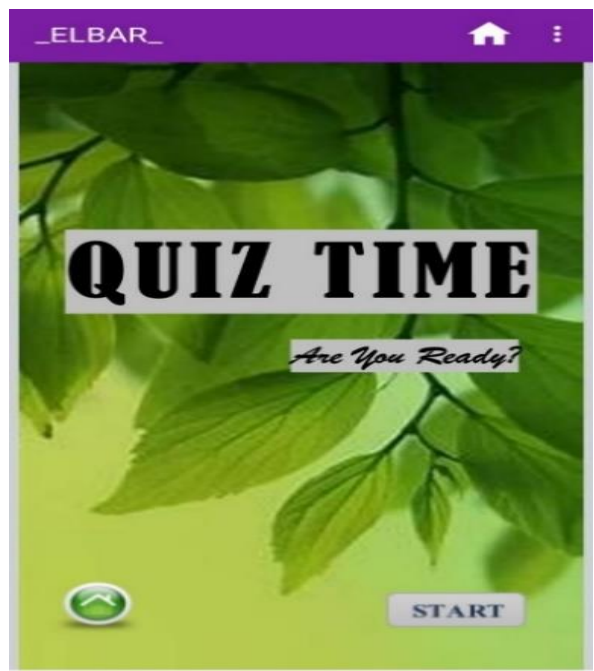

Gambar 8. Tampilan Quiz (Pengayaan Soal) 


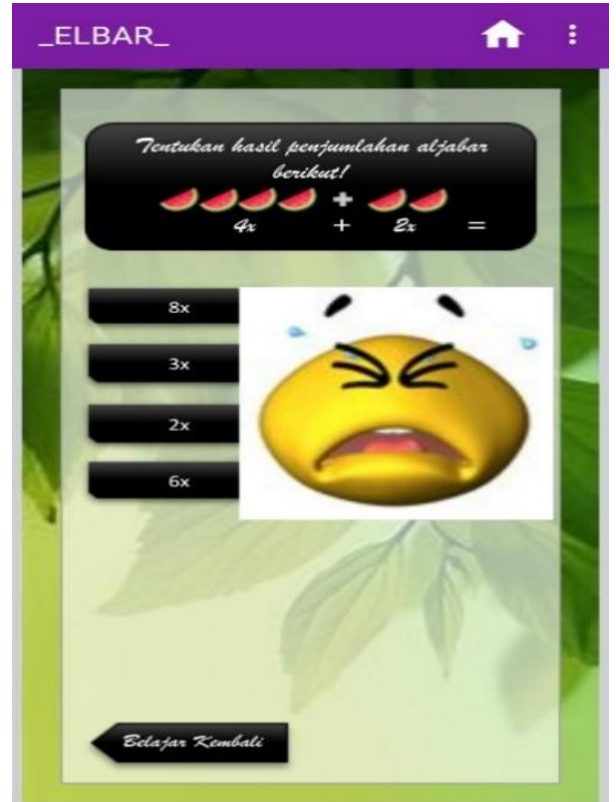

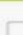

Gambar 9. Tampilan Jika Jawaban Salah

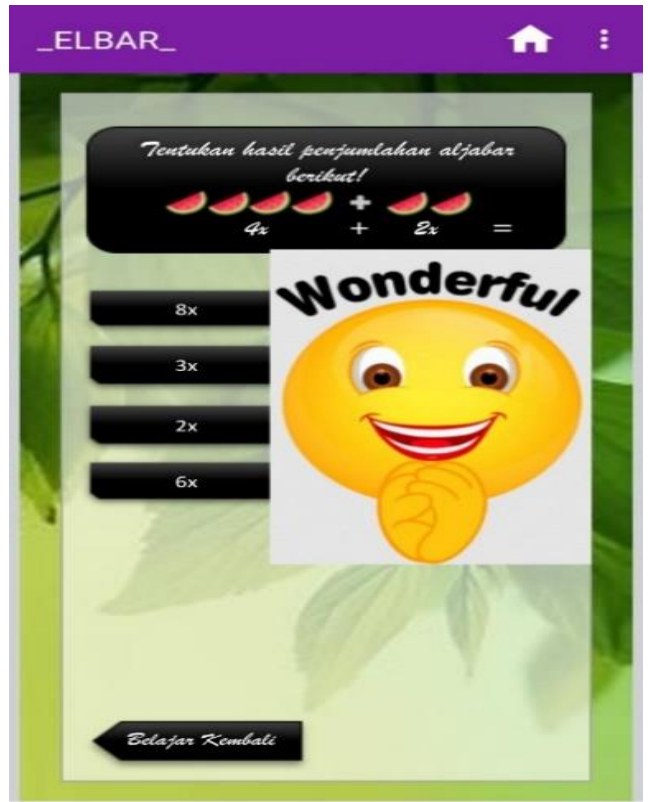

$\square$

Gambar 10. Tampilan Jika Jawaban Benar

Adapun menu evaluasi yang memuat soal evaluasi. Sebelum mengerjakan soal, pengguna akan diminta untuk mengisi nama dan kelas dan setelah selesai pengguna dapat melihat nilai yang diperolehnya.

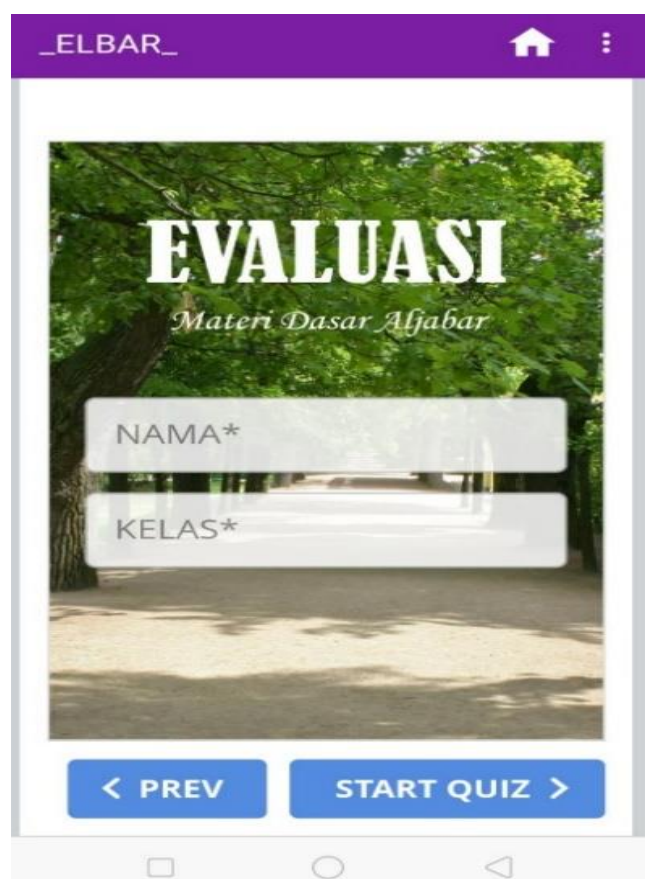

Gambar 11. Tampilan Awal Evaluasi

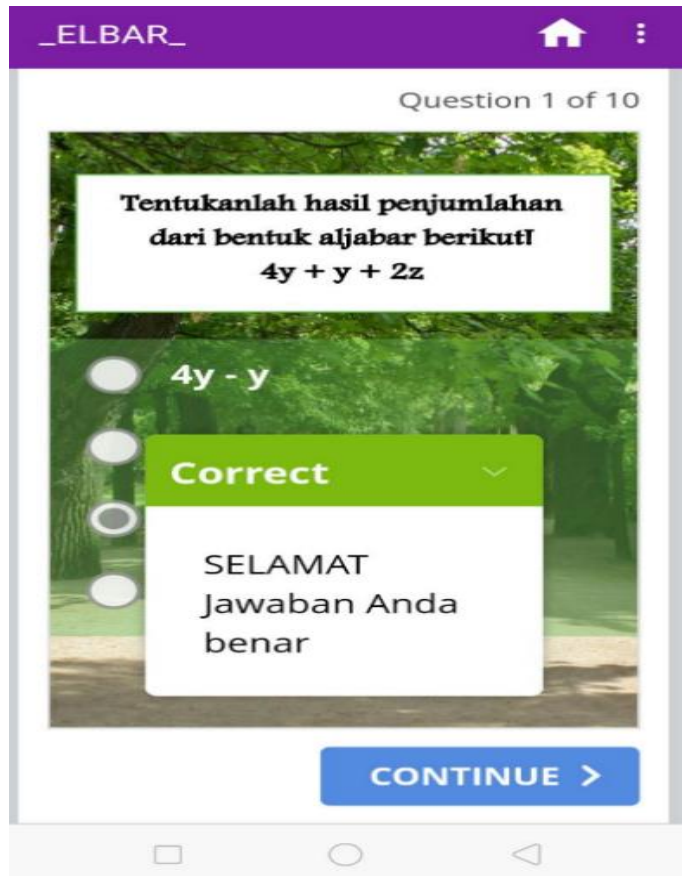

Gambar 12. Tampilan jika Jawaban Benar 


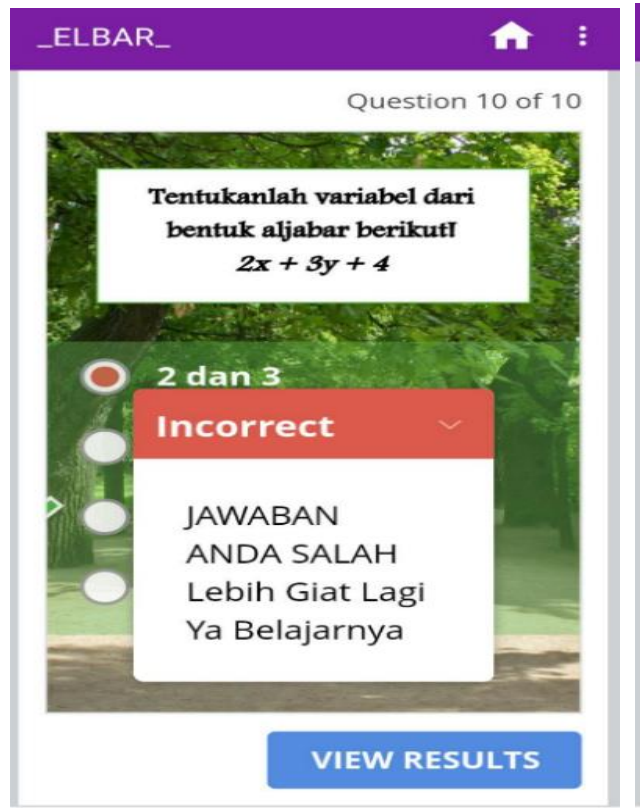

Gambar 13. Tampilan jika Jawaban Salah

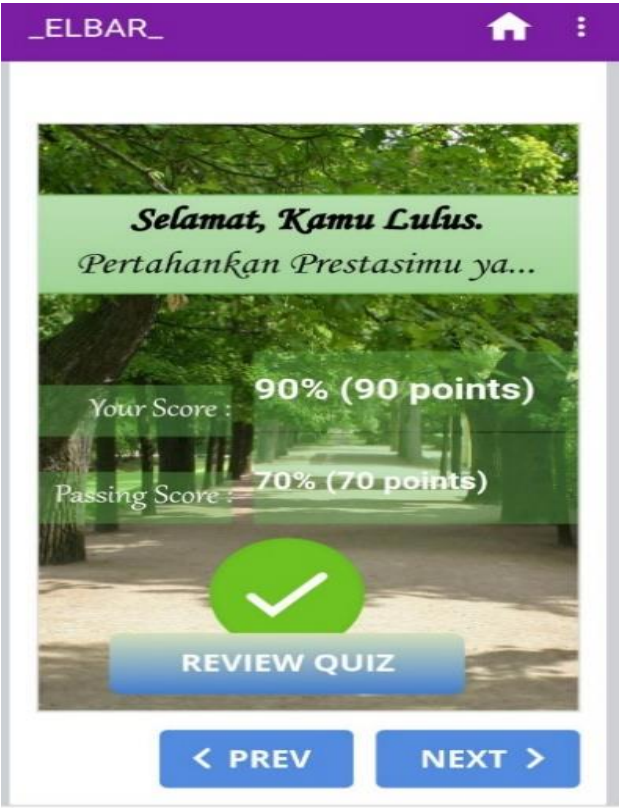

Gambar 14. Tampilan Nilai

Setelah selesai mengembangkan media pembelajaran ini, peneliti akan melakukan validasi untuk menilai kevalidan kepraktisan dan keefektifan media pembelajaran tersebut. Proses validasi ini dilakukan oleh dua ahli materi dan dua ahli media dengan menggunakan instrumen yang telah disiapkan sebelumnya. Validasi ini bertujuan untuk mendapatkan kritik dan saran guna memperbaiki media sebelum diterapkan pada pembelajaran. Adapun hasil penilaian dari ahli media diperoleh skor dengan rata-rata 95,8\% dengan kriteria kelayakan sangat valid dengan beberapa revisi. Sedangkan hasil penilaian dari ahli materi diperoleh skor dengan rata-rata 95,2\% dengan kriteria kelayakan sangat valid tanpa revisi. Beberapa hasil revisi media dapat dilihat pada tabel gambar berikut.

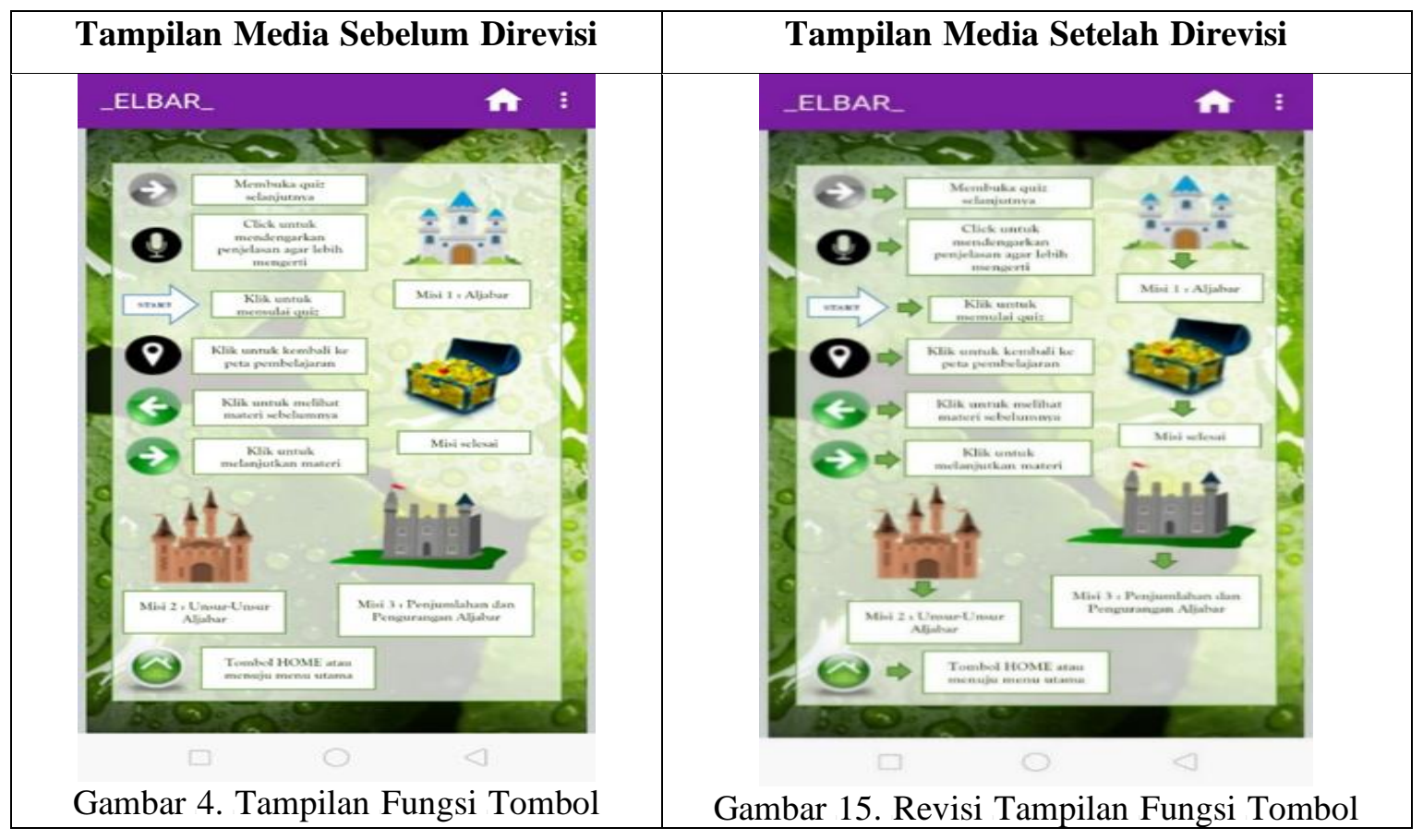




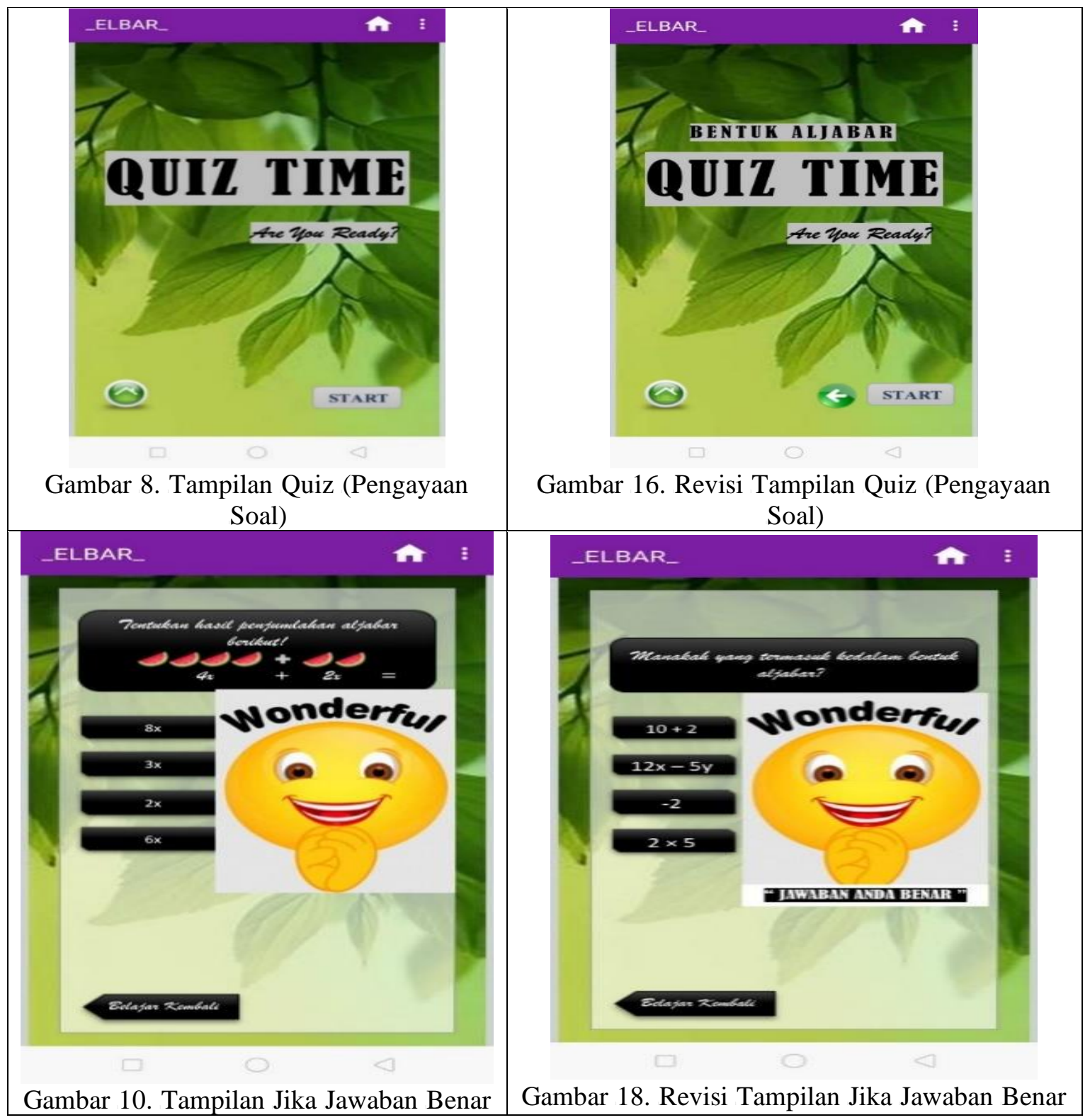

\section{Tahap Implementasi}

Selanjutnya media ini akan diterapkan pada pembelajaran matematika kelas VII MTs AlWashliyah Pematangsiantar dengan jumlah 12 siswa. Langkah awal pada tahap ini ialah memberikan soal pre test untuk mengetahui pemahaman awal siswa. Setelah itu, penerapan media pembelajaran interaktif berbasis android kepada siswa dengan materi bentuk aljabar. Dan langkah terakhir ialah memberikan soal post test untuk mengetahui apakah ada peningkatan pemahaman siswa setelah diterapkannya media tersebut. Dari hasil perbandingan tersebutlah diketahui keefektifan dari media pembelajaran tersebut.

\section{Tahap Evaluasi}

Pada tahap ini, peneliti akan melakukan uji normalitas dari data pre test dan pos test untuk mengetahui apakah data yang didapat berdistribusi normal atau tidak. Berikut ialah hasi dari uji normalitas menggunakan SPSS : 
Tabel 4. Hasil Uji Normalitas

\begin{tabular}{|l|r|r|r|r|r|r|}
\hline \multicolumn{7}{|c|}{ Tests of Normality } \\
\hline & \multicolumn{2}{|c|}{ Kolmogorov-Smirnov ${ }^{\mathrm{a}}$} & \multicolumn{3}{|c|}{ Shapiro-Wilk } \\
\cline { 2 - 8 } & Statistic & \multicolumn{1}{c|}{ df } & \multicolumn{1}{c|}{ Sig. } & Statistic & \multicolumn{1}{c|}{ df } & \multicolumn{1}{c|}{ Sig. } \\
\hline Pretest & .225 & 12 & .095 & .912 & 12 & .224 \\
\hline Posttest & .227 & 12 & .088 & .874 & 12 & .073 \\
\hline
\end{tabular}

a. Lilliefors Significance Correction

Adapun hasil yang didapatkan setelah melakukan uji normalitas Shapiro-Wilk ialah untuk nilai sig. pre test sebesar 0,224 dan nilai sig. post test sebesar 0,073. Karena nilai pre test dan post test > 0,05 maka dapat disimpulkan bahwa data tersebut berdistribusi normal. Uji normalitas Shapiro-Wilk digunakan jika sampel yang diteliti $<50$ sampel. Setelah data berdistribusi normal, selanjutnya akan dilakukan uji Pairet Sample T-Test untuk melihat apakan ada pengaruh dari penggunaan media pembelajaran interaktif tersebut. Berikut ialah hasil dari Uji Paired Sample TTest menggunakan SPSS:

Tabel 5. Hasil Uji Paired Sample T-Test

\begin{tabular}{|c|c|c|c|c|c|c|c|c|c|}
\hline \multicolumn{10}{|c|}{ Paired Samples Test } \\
\hline & & \multicolumn{5}{|c|}{ Paired Differences } & \multirow[b]{3}{*}{$\mathrm{t}$} & \multirow[b]{3}{*}{ df } & \multirow{3}{*}{$\begin{array}{l}\text { Sig. (2- } \\
\text { tailed) }\end{array}$} \\
\hline & & \multirow[b]{2}{*}{ Mean } & \multirow{2}{*}{$\begin{array}{c}\text { Std. } \\
\text { Deviation }\end{array}$} & \multirow{2}{*}{$\begin{array}{l}\text { Std. Error } \\
\text { Mean }\end{array}$} & \multicolumn{2}{|c|}{$\begin{array}{l}95 \% \text { Confidence } \\
\text { Interval of the } \\
\text { Difference }\end{array}$} & & & \\
\hline & & & & & Lower & Upper & & & \\
\hline $\begin{array}{l}\text { Pair } \\
1\end{array}$ & $\begin{array}{l}\text { Pretest - } \\
\text { Posttest }\end{array}$ & $35.833^{-}$ & 15.201 & 4.388 & -45.491 & -26.175 & -8.166 & 11 & .000 \\
\hline
\end{tabular}

Adapun hasil yang didapatkan setelah melakukan Uji Paired Sample T-Test ialah nilai sig. (2-tailed) $<0,005$. Maka dapat disimpulkan bahwa terdapat perbedaan rata-rata hasil pre test dan post test sehingga terdapat pengaruh pada penggunaan media pembelajaran matematika interaktif berbasis android dalam meningkatkan hasil belajar siswa.

Selanjutnya peneliti akan melakukan analisis N-Gain untuk mengetahui keefektifan media pembelajaran tersebut. Berdasarkan hasil perhitungan menggunakan rumus N-Gain, hasil belajar siswa kelas VII MTs Al-Washliyah Pematangsiantar mengalami peningkatan setelah menggunakan media pembelajaran interaktif yang berbasis android sebesar 0,5 dengan kategori sedang dan 63,67\% dengan kategori cukup efektif. Jadi dapat disimpulkan bahwa media pembelajaran matematika interaktif berbasis android pada materi bentuk aljabar efektif untuk digunakan.

Berdasarkan lembar kuesioner uji kepraktisan media yang diisi oleh siswa menunjukkan bahwa media pembelajaran berbasis android mudah dipahami dan digunakan, dapat digunakan kapanpun dan dimanapun dan media ini sangat membantu siswa dalam memahami materi bentuk 
aljabar. Adapun hasil dari uji kepraktisan tersebut diperoleh skor rata-rata 93,05\% dengan kriteria sangat praktis.

Berdasarkan hasil uji validasi ahli media dan materi yang telah dilakukan, maka diketahui bahwa media pembelajaran yang telah dikembangkan valid. Hal ini dapat dilihat dari hasil yang didapatkan $\geq 61 \%$. Dan media pembelajaran ini mampu meningkatkan hasil belajar siswa dalam materi bentuk aljabar, hal ini dapat diketahui melalui hasi uji coba skala kecil yang telah dilakukan. Hal ini sejalan dengan hasil penelitian (Pangestu \& Setyadi, 2020), bahwa penggunaan media pembelajaran interaktif berbasis android dapat meningkatkan hasil belajar matematika siswa.

\section{KESIMPULAN}

Pengembangan media pembelajaran matematika interaktif berbasis android yang diberi nama dengan aplikasi Elbar ini dinyatakan valid digunakan berdasarkan hasil penilaian dari dua ahli materi dan media dengan rata-rata nilai kevalidan $\geq 61 \%$. Adapun nilai rata-rata dari ahli media sebesar 95,8\% dan dari ahli materi sebesar 95,2\% dengan kategori sangat valid.

Media ini juga praktis digunakan pada proses pembelajaran, hal ini dikarenakan media ini dapat digunakan kapanpun dan dimanapun karena media ini bisa diinstal di android. Hal ini juga dibuktikan dengan hasil uji kepraktisan media yang diberikan kepada siswa menunjukkan persentase nilai rata-rata sebesar $93,05 \%$ dengan kategori sangat praktis sehingga media ini praktis digunakan oleh siswa.

Berdasarkan hasil uji paired sample t-test didapatkan hasil yang kurang dari 0,05 sehingga dapat disimpulkan bahwa adanya perbedaan dari hasil belajar siswa dengan rata-rata nilai pre test 43,33 meningkat menjadi 79,13 pada nilai post test nya. Setelah data dianalisis dengan analisis $N$ Gain diperoleh hasil sebesar 0,5 dengan kategori sedang dan 63,67\% dengan kategori cukup efektif. Maka dapat disimpulkan bahwa media ini efektif digunakan untuk meningkatkan hasil belajar siswa pada materi bentuk aljabar.

\section{REFERANSI}

Agus Dwinata, R., Efendi, R., \& Prima Yudha, S. S. (2016). Rancang Bangun Aplikasi Tabel Periodik Unsur dan Perumusan Senyawa Kimia dari Unsur Kimia Dasar Berbasis Android. In Jurnal Rekursif (Vol. 4, Issue 2).

Arikunto, S., \& Jabar, S. A. (2009). Evaluasi Program Pendidikan. Jakarta: Bumi Aksara.

Arliza, R., Setiawan, I., \& Yani, A. (2019). Pengembangan Media Pembelajaran Interaktif Berbasis Android Materi Budaya Nasional dan Interaksi Global Pendidikan Geografi. Jurnal PETIK, 5 (1), 77-84.

Bagja Sulfemi, W., Nurhasanah. (2018). Penggunaan Metode Demontrasi dan Media Audio Visual dalam Meningkatkan Hasil Belajar Peserta Didik Mata Pelajaran IPS. Jurnal Pendas Mahakam, Vol. 3 (2), 151-158. 
Budiman, H. (2016). Penggunaan Media Visual dalam Proses Pembelajaran. Al-Tadzkiyyah: Jurnal Pendidikan Islam, 7, 171-182.

Daryanto. (2010). Media Pembelajaran Perannya Sangat Penting Dalam Mencapai Tujuan Pembelajaran. Yogyakarta: Gava Media.

Dwiranata, D., Pramita, D. (2019). Pengembangan Media Pembelajaran Matematika Interaktif Berbasis Android Pada Materi Dimensi Tiga Kelas X SMA (Vol. 3, Issue 1).

Ernanida. (2019). Media Audio Visual dalam Pembelajaran PAI. Murabby: Jurnal Pendidikan Islam, 2(1), 101-112. https://ejournal.uinib.ac.id/jurnal/index.php/murabby.

Halimah, A., \& Andi Mattoliang, L. (2020). Pengembangan Media Pembelajaran Interaktif Berbasis Multimedia. Al asma: Journal of Islamic Education ISSN (Vol. 2, Issue 1). Online.

Hudojo, H. (2005). Pengembangan Kurikulum dan Pembelajaran Matematika. Surabaya: UM Press.

Irfan, D., Hapsari, S., Fahmi, S. (2021). Pengembangan Media Pembelajaran Interaktif Berbasis Android Pada Operasi Pada Matriks. https://doi.org/10.24853/fbc. FIBONACCI: Jurnal Pendidikan Matematika dan Matematika, 7(1), 51-60.

Khuzaini, N., \& Yogo Sulistyo, T. (2020). Pengembangan Media Pembelajaran Interaktif Berbasis Android Menggunakan Adobe Flash CS6 pada Materi Segiempat dan Segitiga. Prosiding Konferensi Pendidikan Nasional, 2 (1), 178-183.

Komariah, S., Suhendri, H., Arif, D., \& Hakim, R. (2018). Pengembangan Media Pembelajaran Matematika Siswa SMP Berbasis Android How to Cite (APA 6 th Style. 4(1), 43-52. http://journal.lppmunindra.ac.id/index.php/jkpm/

Lestari Dan Istiqomah, N. A. (2017). Pengembangan Multimedia Pembelajaran Kurikulum 2013 pada Pokok Bahasan Trigonometri di SMK. Jurnal Pendidikan Matematika (Vol. 5, Issue 3).

Lestari, A. I., Senjaya, A. J., Ismunandar, D. (2019). Pengembangan Media Pembelajaran Berbasis Android Menggunakan Appy Pie Untuk Melatih Pemahaman Konsep Turunan Fungsi Aljabar. 4 (2), 96-105.

Munir. (2012). Multimedia Konsep dan Aplikasi dalam Pendidikan. Bandung: Alfabeta.

Pangestu, Y. S., \& Setyadi, D. (2020). Pengembangan Media Pembelajaran Aplikasi Android Pytha Fun untuk Teorema Pythagoras SMP. 04(01), 113-125.

Putra, R. S., Wijayati, N., \& Mahatmanti, F. W. (2017). Pengeruh Penggunaan Media Pembelajaran Berbasis Aplikasi Android Terhadap Hasil Belajar Siswa. Jurnal Inovasi Pendidikan Kimia, 11 (2), 2009-2018.

Putri, I. P., \& Sibuea, A. M. (2014). Pengembangan Media Pembelajaran Interaktif pada Mata Pelajaran Fisika. Jurnal Teknologi Informasi \& Komunikasi dalam Pendidikan, 1(2), 145-155.

Ramli, M. (2015). Media Pembelajaran dalam Perspektif Al-Qur'an dan Al-Hadits. In Ittihad Jurnal Kopertais Wilayah XI Kalimantan (Vol. 13, Issue 23). 
Sattriawan, A., Sutiarso, S., Rosidin, U. (2020). Pengembangan Media Pembelajaran Interaktif Terintegrasi Soft Skills dalam Meningkatkan Kemampuan Pemecahan Masalah. Jurnal Cendekia: Jurnal Pendidikan Matematika, 04 (02), 950-963.

Sri Mulyani, E. W. (2018). Dampak Pemanfaatan Aplikasi Android dalam Pembelajaran Bangun Ruang. Kwangsan: Jurnal Teknologi Pendidikan, 6(2), 122- 136. https://doi.org/10.31800/jtp.kw.v6n2.p122--136.

Yektyastuti, R., \& Ikhsan, J. (2016). Pengembangan media pembelajaran berbasis android pada materi kelarutan untuk meningkatkan performa akademik siswa SMA. Jurnal Inovasi Pendidikan IPA, 2(1), 88. https://doi.org/10.21831/jipi.v2i1.10289. 